\title{
Mechanical ventilation augments bleomycin-induced epithelial-mesenchymal transition through the Src pathway
}

\author{
Li-Fu Li ${ }^{1,2}$, Yung-Yang Liu ${ }^{3,4}$, Kuo-Chin Kao ${ }^{1,2}$, Chen-Te Wu ${ }^{5,6}$, Chih-Hao Chang ${ }^{1}$, Chen-Yiu Hung ${ }^{1}$ and \\ Cheng-Ta Yang ${ }^{1,2}$
}

\begin{abstract}
Mechanical ventilation used in patients with acute respiratory distress syndrome (ARDS) can damage pulmonary epithelial cells by producing inflammatory cytokines and depositing excess collagen. Src participates in plasminogen activator inhibitor-1 (PAI-1) and transforming growth factor- $\beta 1$ (TGF- $\beta 1$ ) production during the fibroproliferative phase of ARDS, which involves a process of epithelial-mesenchymal transition (EMT). The mechanisms regulating interactions between mechanical ventilation and EMT are unclear. We hypothesized that EMT induced by high-tidal volume $\left(\mathrm{V}_{T}\right)$ mechanical stretch-augmented lung inflammation occurs through upregulation of the Src pathway. Five days after administering bleomycin to simulate acute lung injury (ALI), male C57BL/6 mice, either wild-type or Src-deficient, aged 3 months, weighing between 25 and $30 \mathrm{~g}$, were exposed to low- $V_{T}(6 \mathrm{ml} / \mathrm{kg})$ or high $-V_{T}(30 \mathrm{ml} / \mathrm{kg})$ mechanical ventilation with room air for $1-5 \mathrm{~h}$. Nonventilated mice were used as control subjects. We observed that high- $\mathrm{V}_{\mathrm{T}}$ mechanical ventilation increased microvascular permeability, PAI- 1 and TGF- $\beta 1$ protein levels, Masson's trichrome staining, extracellular collagen levels, collagen gene expression, fibroblast accumulation, positive staining of $\alpha$-smooth muscle actin and type I collagen, activation of Src signaling and epithelial apoptotic cell death in wild-type mice $(P<0.05)$. Decreased staining of the epithelial marker, Zonula occludents-1, was also observed. Mechanical stretch-augmented EMT and epithelial apoptosis were attenuated in Src-deficient mice and pharmacological inhibition of Src activity by PP2 $(P<0.05)$. Our data suggest that high- $\mathrm{V}_{\mathrm{T}}$ mechanical ventilation-augmented EMT after bleomycin-induced ALI partially depends on the Src pathway. Laboratory Investigation (2014) 94, 1017-1029; doi:10.1038/labinvest.2014.75; published online 23 June 2014
\end{abstract}

Acute respiratory distress syndrome (ARDS) is a disorder of acute respiratory failure and manifests as non-cardiogenic pulmonary edema, respiratory distress and hypoxemia. ${ }^{1,2}$ Mechanical ventilation with high-tidal volume $\left(\mathrm{V}_{\mathrm{T}}\right)$ causes severe lung injury (ventilator-induced lung injury (VILI)) characterized by an initial inhomogeneous inflammatory reaction or epithelial injury that is followed by a fibroproliferative phase with fibroblast proliferation. ${ }^{3-8}$ Epithelialmesenchymal transition (EMT) is the differentiation of epithelial cells into myofibroblast-like cells, which contributes to the fibroproliferative phase. ${ }^{3-8}$ Upregulating Src, the plasminogen activator inhibitor-1 (PAI-1), and the transforming growth factor- $\beta 1$ (TGF- $\beta 1$ ) has recently been demonstrated to regulate EMT. ${ }^{9-14}$ However, the mechanisms regulating the interactions between mechanical ventilation and EMT remain unclear.

PAI-1, a member of the serine protease inhibitor (serpin) gene family, rapidly inhibits both the urokinase-type plasminogen activator and the tissue-type plasminogen activator (tPA). ${ }^{15}$ Mice with homozygous deletion of PAI-1 were relatively protected from bleomycin-induced pulmonary fibrogenesis, whereas overexpression of PAI- 1 enhanced pulmonary fibrogenesis. ${ }^{9}$ As a primary profibrogenic cytokine, TGF- $\beta 1$ is crucial in both the acute inflammatory response and subsequent wound remodeling of patients with ARDS. ${ }^{16}$ TGF- $\beta 1$ is produced by various cells, including epithelial cells and fibroblasts and can be activated by numerous stimuli, including plasmin, reactive oxygen

\footnotetext{
'Division of Pulmonary and Critical Care Medicine, Department of Internal Medicine, Chang Gung Memorial Hospital and Chang Gung University, Taoyuan, Taiwan; ${ }^{2}$ Department of Respiratory Therapy, Chang Gung Memorial Hospital, Taoyuan, Taiwan; ${ }^{3}$ Chest Department, Taipei Veterans General Hospital, Taipei, Taiwan; ${ }^{4}$ Institute of Clinical Medicine, School of Medicine, National Yang-Ming University, Taipei, Taiwan; ${ }^{5}$ Department of Medical Imaging and Intervention, Chang Gung Memorial Hospital, Taoyuan, Taiwan and ${ }^{6}$ Department of Biomedical Imaging and Radiological Sciences, National Yang-Ming University, Taipei, Taiwan

Correspondence: Professor C-T Yang, MD, Division of Pulmonary and Critical Care Medicine, Department of Internal Medicine, Chang Gung Memorial Hospital, 5 FuHsing Street, Kweishan, Taoyuan 333, Taiwan.
}

E-mail: yang1946@adm.cgmh.org.tw

Received 22 January 2014; revised 20 April 2014; accepted 20 May 2014 
species, radiation and thrombospondin. ${ }^{17}$ In addition, recent studies of the fibrotic human lung have demonstrated that TGF- $\beta 1$ induced alveolar type II cells to acquire features of mesenchymal cells. ${ }^{10}$

High- $\mathrm{V}_{\mathrm{T}}$ mechanical stretch of alveolar epithelial cells leads to abnormal wound healing by inducing EMT. ${ }^{3}$ EMT is characterized by loss of epithelial markers (E-cadherin, Zonula occludents (ZO)-1), cytoskeletal reorganization and transition to a spindle-shaped morphology concurrent with acquisition of mesenchymal markers ( $\alpha$-smooth muscle actin ( $\alpha$-SMA) and collagen I). ${ }^{18}$ Mechanical stretchinduced activation of Src has recently been demonstrated to increase lung vascular permeability in mice. ${ }^{13} \mathrm{Src}$ protein tyrosine kinase family is categorized into nonreceptor tyrosine kinases and is one of the most crucial families for intracellular signal transduction related to cell proliferation, migration, differentiation and apoptotic cell death. ${ }^{14,19,20} \mathrm{Src}$ inhibitors that are used in vivo may suppress inflammatory responses, involving neutrophils, monocytes, macrophages, endothelial and epithelial cells. ${ }^{21,22}$ Given the absence of a proven effective treatment for acute lung injury (ALI) and EMT, Src inhibition may provide an attractive target in the devastating process of patients with ARDS. ${ }^{14,23}$

In this high- $\mathrm{V}_{\mathrm{T}}$ ventilation-induced lung injury model of mice pretreated with bleomycin, we compared the effects among various $V_{T}$ of mechanical ventilation, the correlation of EMT to fibroblast accumulation and epithelial apoptosis, and the production of PAI- 1 and TGF- $\beta 1$ using pharmacological inhibitors PP2 and Src-deficient mice. We hypothesized that high $\mathrm{V}_{\mathrm{T}}$ mechanical ventilation-augmented lung inflammation contributed to the process of EMT secondary to activating the Src pathway.

\section{MATERIALS AND METHODS Experimental Animals}

Male C57BL/6, either wild-type or Src-deficient on a C57BL/ 6 background, weighing between 20 and $25 \mathrm{~g}$, aged between 6 and 8 weeks, were obtained from Jackson Laboratories (Bar Harbor, ME, USA) and National Laboratory Animal Center (Taipei, Taiwan). ${ }^{24}$ Briefly, heterozygotes $\left(\mathrm{Src}^{+/-}\right.$) were used because mice homozygous for $\mathrm{Src}^{\mathrm{tm} 1 \text { Sor }}$ targeted mutation $\left(\mathrm{Src}^{-1-}\right)$ exhibit growth retardation, failure of tooth eruption, osteopetrosis with lack of secondary bone resorption and lethality at 3-4 weeks. ${ }^{24}$ Mice that were heterozygous for the $\mathrm{Src}^{\text {tm1Sor }}$ mutation $\left(\mathrm{Src}^{+/-}\right)$, however, have no apparent abnormalities. ${ }^{24}$ The target mutation of Src was constructed by inserting a neomycin cassette into the first coding exon and is electroporated into 129S7/SvEvBrdHprt derived AB2.1 embryonic stem (ES) cells. ${ }^{24}$ Northern blot analysis confirmed that no wild-type transcript was present in homozygous mice. Chimeras are generated by injecting these ES cells into C57BL/6 (B6) blastocysts. The resulting chimeric male animals are crossed to C57BL/6 mice, and then backcrossed to the same for 10 generations. The lower expression levels of the Src protein in $\mathrm{Src}^{+/-}$mice were confirmed by using western blot analysis. The study was performed in strict accordance with the recommendations in the Guide for the Care and Use of Laboratory Animals of the National Institutes of Health. The protocol was approved by the Institutional Animal Care and Use Committee of Chang Gung Memorial Hospital (Permit number: 2011093005). All surgery was performed under ketamine and xylazine anesthesia, and all efforts were made to minimize suffering.

\section{Ventilator Protocol}

We used our established mouse model of VILI, as previously described. ${ }^{5}$ In brief, a 20 -gauge angiocatheter was introduced into the tracheotomy orifice of mice under general anesthesia with intraperitoneal ketamine $(90 \mathrm{mg} / \mathrm{kg})$ and xylazine $(10 \mathrm{mg} / \mathrm{kg})$. The mice then received $0.9 \%$ saline containing maintenance ketamine $(0.1 \mathrm{mg} / \mathrm{g} / \mathrm{h})$ and xylazine $(0.01 \mathrm{mg} / \mathrm{g} /$ h) at a rate of $0.09 \mathrm{ml} / 10 \mathrm{~g} / \mathrm{h}$ by a continuous intraperitoneal fluid pump. The mice were placed in a supine position on a heating blanket and then attached to a Harvard apparatus ventilator, model 55-7058 (Harvard Apparatus, Holliston, MA, USA), set to deliver either $6 \mathrm{ml} / \mathrm{kg}$ at a rate of 135 breaths per min or $30 \mathrm{ml} / \mathrm{kg}$ at a rate of 65 breaths per min, for $1-5 \mathrm{~h}$ while breathing room air with zero end expiratory pressure. The $\mathrm{V}_{\mathrm{T}}$ delivered by the ventilator was checked by fluid displacement from an inverted calibration cylinder. Continuous monitoring of end-tidal $\mathrm{CO}_{2}$ by a microcapnograph (Columbus Instruments, Columbus, OH, USA) was performed, and respiratory frequencies of 135 breaths per min for $6 \mathrm{ml} / \mathrm{kg}$ and 65 breaths per min for $30 \mathrm{ml} / \mathrm{kg}$ were chosen in the experiment, with end-tidal $\mathrm{CO}_{2}$ at 30 to $40 \mathrm{~mm} \mathrm{Hg}$. Airway peak inspiratory pressure was measured with a pressure-transducer amplifier (Gould Instrument Systems, Valley View, OH, USA) connected to the tubing at the proximal end of the tracheostomy. Mean arterial pressure was monitored every hour during mechanical ventilation by using the same pressure-transducer amplifier connected to a $0.61-\mathrm{mm}$ outer diameter $(0.28-\mathrm{mm}$ inner diameter) polyethylene catheter ending in the common carotid artery. One hour of mechanical ventilation was used for western blot analysis, and $5 \mathrm{~h}$ was applied for PAI- 1 and TGF- $\beta 1$ production, cell counts, lung water, Evans blue dye (EBD), total collagen, collagen gene, electron microscopy and histologic staining analyses, based on previous studies. ${ }^{5,25}$ At the end of the study period, heparinized blood was taken from the arterial line for analysis of arterial blood gas, and the mice were killed. The nonventilated control mice were anesthetized and killed immediately. The experimental group of animals and procedures used in this study is summarized in Table 1.

\section{Bleomycin and PP2 Administration}

The mice received a single dosage of 0.075 units of bleomycin in $100 \mu \mathrm{l}$ of sterile normal saline (Sigma, St Louis, MO) intratracheally, and were ventilated 5 days after administering bleomycin. ${ }^{5}$ PP2 is a Src inhibitor $(2 \mathrm{mg} / \mathrm{kg}$; Calbiochem, 
Table 1 Experimental design and numbers of animals per group

\begin{tabular}{|c|c|c|c|c|c|c|c|}
\hline & $\begin{array}{l}\text { EBD, lung } \\
\text { water (5 h) }\end{array}$ & $\begin{array}{l}\text { PAI-1, TGF- } \beta 1 \text {, collagen, } \\
\text { total protein }(5 \mathrm{~h})\end{array}$ & $\begin{array}{l}\text { Src protein } \\
\quad(1 \mathrm{~h})\end{array}$ & $\begin{array}{l}\mu \mathrm{CT} \\
(5 \mathrm{~h})\end{array}$ & $\begin{array}{l}\text { EM } \\
(5 \mathrm{~h})\end{array}$ & $\begin{array}{c}\text { Isolated } \\
\text { fibroblasts }(5 \mathrm{~h})\end{array}$ & $\begin{array}{l}\text { IF, IHC, Trichrome } \\
\text { stain, TUNEL }(5 \mathrm{~h})\end{array}$ \\
\hline Control (wild type with bleomycin) ${ }^{-}$ & 5 & 5 & 5 & 5 & 3 & 5 & 5 \\
\hline $\mathrm{V}_{\mathrm{T}} 6 \mathrm{ml} / \mathrm{kg}$ (wild type with bleomycin) & 5 & 5 & 5 & 0 & 0 & 0 & 5 \\
\hline $\mathrm{V}_{\mathrm{T}} 30 \mathrm{ml} / \mathrm{kg}\left(\mathrm{Src}^{+/-}\right.$with bleomycin $)$ & 5 & 5 & 5 & 5 & 3 & 5 & 5 \\
\hline
\end{tabular}

Abbreviations: Control, spontaneously breathing, nonventilated mice; EBD, Evans blue dye; EM, electron microscopy; IF, immunofluorescence; IHC, immunohistochemistry; $\mu \mathrm{CT}$, micro-computer tomography; PAI-1, plasminogen activator inhibitor-1; Src ${ }^{+/-}$, Src-deficient mice; TGF- $\beta 1$, transforming growth factor- $\beta 1$; TUNEL, terminal deoxynucleotidyl transferase-mediated dUTP-biotin nick end-labeling assay; $\mathrm{V}_{\mathrm{T}}$, tidal volume.

La Jolla, CA, USA), and was given intraperitoneally $30 \mathrm{~min}$ before mechanical ventilation, based on previous in vivo study that showed $2 \mathrm{mg} / \mathrm{kg}$ PP2 inhibited Src activity and lung injury. ${ }^{22}$

\section{Collagen Assay}

The lungs were homogenized and collagen was solubilized in $0.5 \mathrm{M}$ acetic acid. The protein extracts were incubated with Sirius red dye and levels of collagen in lung tissues was determined at absorbance of $540 \mathrm{~nm}$ by SIRCOL collagen assay kit (Biocolor, UK) according to the manufacturer's instructions. Amount of collagen was expressed in $\mu \mathrm{g} / \mathrm{g}$ of wet lung weight.

\section{Measurement of PAI-1 and TGF- $\beta 1$}

At the end of the study period, the lungs were lavaged via tracheostomy with 20-gauge angiocatheter (sham instillation) three times with $0.6 \mathrm{ml}$ of $0.9 \%$ normal saline. The effluents were pooled and centrifuged at $310 \times g$ for $10 \mathrm{~min}$. Supernatants were frozen at $-80^{\circ} \mathrm{C}$ for further analysis of the cytokine. PAI- 1 with a lower detection limit of $0.02 \mathrm{ng} / \mathrm{ml}$ and active TGF- $\beta 1$ with a lower detection limit of $4.61 \mathrm{pg} / \mathrm{ml}$ were measured in BAL fluid using a commercially available immunoassay kit containing primary polyclonal anti-mouse antibodies that were cross-reactive with rat and mouse PAI-1 (Molecular Innovations, Southfield, MI, USA) and TGF- $\beta 1$ (Biosource International, Camarillo, CA, USA). Each sample was run in duplicate according to the manufacturer's instructions.

\section{Immunoblot Analysis}

The lungs were homogenized in $3 \mathrm{ml}$ of lysis buffer $(20 \mathrm{mM}$ HEPES pH 7.4, $1 \%$ Triton X-100, $10 \%$ glycerol, $2 \mathrm{mM}$ ethylene glycol-bis ( $\beta$-aminoethyl ether)-N, N, N', N'-tetraacetic acid, $50 \mu \mathrm{M} \quad \beta$-glycerophosphate, $1 \mathrm{mM}$ sodium orthovanadate, $1 \mathrm{mM}$ dithiotreitol, $400 \mu \mathrm{M}$ aprotinin and $400 \mu \mathrm{M}$ phenylmethylsulfonyl fluoride), transferred to eppendorf tubes and placed on ice for $15 \mathrm{~min}$. Tubes were centrifuged at $15350 \times \mathrm{g}$ for $10 \mathrm{~min}$ at $4{ }^{\circ} \mathrm{C}$ and supernatant was flash-frozen. Crude cell lysates were matched for protein concentration, resolved on a $10 \%$ bis-acrylamide gel and electrotransferred to Immobilon-P membranes (Millipore, Bedford, MA, USA). For assay of Src phosphorylation and Src total protein expression, western blot analyses were performed with antibodies of phospo-Src and $\mathrm{Src}$ (Santa Cruz Biotechnology, Santa Cruz, CA). Blots were developed by enhanced chemiluminescence (NEN Life Science Products, Boston, MA, USA).

\section{Immunofluorescence Labeling}

Isolated fibroblasts in lung tissue were fixed in cold methanol. The lung tissues were paraffin embedded, sliced at $4 \mu \mathrm{m}$, deparaffinized and stained according to the manufacturer's instruction for an immunohistochemical kit (Santa Cruz Biotechnology). Isolated cells and lung sections were incubated with primary rabbit anti-mouse antibodies of ZO-1, $\alpha$-SMA, and collagen I (1:100; New England BioLabs, Beverly, MA, USA) and fluorescent secondary antibodies of Cy3-conjugated anti-rabbit (ZO-1, $\alpha$-SMA) and FITCconjugated affinity purified anti-goat (collagen I; 1:1000; Santa Cruz Biotechnology). Nuclear staining was performed using Hoechst solution $(0.5 \mu \mathrm{g} / \mathrm{ml}$; Sigma). The fluorescencelabeled slides were subsequently examined using a Leica TCS 4D confocal laser scanning microscopy system (Leica, Wetzlar, Germany).

\section{Fibroblast Isolation}

The lungs were perfused with cold phosphate-buffered saline, and the parenchyma was excised. Large airways were carefully removed, and the lungs were minced finely and incubated in RPMI 1640 with $10 \mathrm{mM}$ HEPES, $20 \mathrm{mM}$ L-glutamine, $10 \%$ fetal cuff serum, $1 \%$ penicillin-streptomycin, $20 \mathrm{U} / \mathrm{ml}$ of collagenase and $1 \mu \mathrm{g} / \mathrm{ml}$ of type I DNase (Sigma). After incubating for $60 \mathrm{~min}$ at $37^{\circ} \mathrm{C}$ on a rotary agitator, any remaining intact tissue fragments were removed using 100 and $40 \mu \mathrm{m}$ filters (BD Biosciences, NJ, USA), and cells were 
collected through centrifugation. The cell pellets were cytospined for immunofluorescent labeling or flash-frozen for western blot analysis. ${ }^{26}$

\section{Terminal Deoxynucleotidyl Transferase-Mediated dUTP-Biotin Nick End-Labeling (TUNEL) Assay}

The lung tissues were paraffin embedded, sliced at $4 \mu \mathrm{m}$ and stained with a terminal deoxynucleotidyl transferase TUNEL labeling reaction mixture using Fluorescein-FragEL ${ }^{\mathrm{TM}}$ DNA fragmentation detection kit according to the manufacturer's instructions (Oncogen Research Products, Boston, MA, USA). This method measured both apoptotic and necrotic cells. The specimens were further examined with a Leica TCS 4D confocal laser scanning microscopy system (Leica). A bright green signal indicated positive staining of apoptotic cells, whereas shades of dull green signified nonreactive cells. Apoptosispositive cells were quantified as the average number of epithelial cells with bright green signals per bronchiole, which were counted from 10 nonoverlapping fields by a single investigator blinded to therapeutic category of the mouse.

\section{Transmission Electron Microscopy}

The lungs were fixed in $3 \%$ glutaraldehyde in $0.1 \mathrm{M}$ cacodylate buffer ( $\mathrm{pH} 7.4)$ for $1 \mathrm{~h}$ at $4{ }^{\circ} \mathrm{C}$. The lungs were then postfixed in $1 \%$ osmium tetroxide ( $\mathrm{pH} 7.4$ ), dehydrated in a graded series of ethanol and embedded in EPON-812. Thin sections $(70 \mathrm{~nm})$ were cut, stained with uranyl acetate and lead citrate, and examined on a Hitachi H-7500 EM transmission electron microscope (Hitachi, Tokyo, Japan).

\section{Micro-Computer Tomography}

At the end of the study period, the lung samples were scanned using a micro-computer tomography ( $\mu \mathrm{CT}$ ) imaging system (Bioscan, CA, USA). The helical $\mu \mathrm{CT}$ data were acquired using a high-resolution frame as the system setup, with tube voltage of $65 \mathrm{keV}$, pitch of 1.0 and 360 projections. The axial scanning range was set at $2 \mathrm{~cm}$ with the two parietal defects in the center of the field of view. The $\mu \mathrm{CT}$ images with a matrix size of $400 \times 400 \times 402$ and an isotropic voxel size of $0.1 \mathrm{~mm}$ were reconstructed. ${ }^{27}$ The $3 \mathrm{D}$ surface-rendering images were generated using the Avizo software (Visualization Science Group, MA, USA) with the segmentation threshold determined from pilot scans of several specimens.

\section{Analysis of Lung Water}

Lungs were removed en bloc, and large airways were removed. Both lungs were weighed and then dried in an oven at $80^{\circ} \mathrm{C}$ for $48 \mathrm{~h}$. If no changes were found in the dry lung weight at 24 and $48 \mathrm{~h}$, the weight at $48 \mathrm{~h}$ was used. Lung wetto-dry weight ratio was used as an index of pulmonary edema formation.

\section{BAL Total Protein}

Total protein concentration in the BAL was determined with the Bio-Rad Dc Protein Assay Kit (Bio-Rad Laboratories,
Hercules, CA, USA) according to the manufacturer's instructions.

\section{Collagen Gene Expression}

For isolating total RNA, the lung tissues were homogenized in TRIzol reagents (Invitrogen, Carlsbad, CA, USA) according to the manufacturer's instructions. Total RNA $(1 \mu \mathrm{g})$ was reverse transcribed by using a GeneAmp PCR system 9600 (PerkinElmer Life Sciences, Boston, MA, USA), as previously described. ${ }^{5}$ The following primers were used for real-time polymerase chain reaction (PCR): collagen 1a1, forward primer $5^{\prime}$-CCAAGGGTAACAGCGGTGAA- $3^{\prime}$ and reverse primer $5^{\prime}$-CCTCGTTTTCCTTCTTCTCCG-3'; collagen 1a2, forward primer $5^{\prime}$-TGTTGGCCCATCTGGTAAAGA-3 ${ }^{\prime}$ and reverse primer $5^{\prime}$-CAGGGAATCCGATGTTGCC- $3^{\prime}$; collagen 3al, forward primer $5^{\prime}$-TCAAGTCTGGAGTGGGAGG- $3^{\prime}$ and reverse primer $5^{\prime}$-TCCAGGATGTCCAGAAGAACC- $3^{\prime}$; and GAPDH as internal control, forward primer $5^{\prime}$-AATGCATCC TGCACCACCAA- $3^{\prime}$ and reverse primer $5^{\prime}$-GTAGCCATATTC ATTGTCATA-3' (Integrated DNA Technologies, Coralville, IA, USA). ${ }^{28}$ All quantity PCR reactions using SYBR Master Mix were performed on an ABI Prism 7000 sequence detector PCR system (Applied Biosystems, Foster City, CA, USA).

\section{Masson's Trichrome Stain and Fibrosis Scoring}

The lung tissues from the nonventilated control mice, mice exposed to high- $V_{T}$ or low $-V_{T}$ ventilation for $5 \mathrm{~h}$ while breathing room air were paraffin embedded, sliced at $4 \mu \mathrm{m}$, deparaffinized, stained sequentially with Weigert's iron hematoxylin solution, Biebrish scarlet-acid fuchsin solution and aniline blue solution according to the manufacturer's instruction of a trichrome kit (Sigma). A blue signal indicated positive staining of collagen. The fibrotic grade of each lung field was assessed using the criteria of Ashcroft, ranging from grade 0 to 5 as follows: grade 0: normal lung; grade 1: minimal fibrous thickening of alveolar or bronchial walls; grade 2: moderate thickening of walls without obvious damage to lung architecture; grade 3 : increased fibrosis with definite damage to lung structure and formation of fibrous bands or small fibrous masses; grade 4: severe distortion of structure and large fibrous areas (honeycomb lung); grade 5: total fibrous obliteration in the field. ${ }^{5}$ Average number of 10 nonoverlapping fields in Masson's trichrome staining of paraffin lung sections, five mice per group, were analyzed for each section by a single investigator blinded to the mouse genotype.

\section{Statistical Evaluation}

The western blots were quantitated using a National Institutes of Health (NIH) image analyzer Image J $1.27 \mathrm{z}$ (National Institutes of Health, Bethesda, MD, USA) and presented as arbitrary units. Values were expressed as the mean \pm s.d. from at least five separate experiments. The data of EBD assay, lung wet-to-dry weight ratio, PAI-1 and 
TGF- $\beta 1$, total collagen content, collagen gene expression, fibrosis score, histopathologic assay and oxygenation were analyzed using Statview 5.0 (Abascus Concepts, Cary, NC, USA; SAS Institute). All results of western blots and real-time PCR were normalized to the nonventilated control wild-type mice with bleomycin treatment. ANOVA was used to assess the statistical significance of the differences, followed by multiple comparisons with a Scheffe's test, and a $P$-value $<0.05$ was considered statistically significant. EBD analysis and immunohistochemistry were performed as previously described. ${ }^{5}$

\section{RESULTS}

\section{Reduction of VILI in Src-Deficient Mice and by PP2}

We used high- $\mathrm{V}_{\mathrm{T}}(30 \mathrm{ml} / \mathrm{kg})$ and low- $\mathrm{V}_{\mathrm{T}}(6 \mathrm{ml} / \mathrm{kg})$ ventilation with room air for $5 \mathrm{~h}$ to induce VILI in mice and examined the injurious effects of overdistension and treatment effects of intraperitoneally delivered PP2. The physiological conditions at the beginning and end of ventilation are shown in Table 2. The normovolemic statuses of mice were maintained by monitoring their mean artery pressure. The gross pathologic results indicated that the animal lungs injured by mechanical ventilation at $\mathrm{V}_{\mathrm{T}} 30 \mathrm{ml} / \mathrm{kg}$, displayed a hemorrhaging pattern, severe congestion and enlargement because of edema, and an EBD leak associated with changes of microvascular permeability (Figure 1a). In addition, we used $\mu \mathrm{CT}$, an essential component for monitoring the lung fibrogenesis in vivo, to examine the damaged lung structure. ${ }^{27}$ Evidence of pulmonary fibrogenesis and damage, including increased honeycombing, reticular opacities, traction bronchiectasis and ground glass opacities in both lower lungs was observed in mice ventilated at $\mathrm{V}_{\mathrm{T}} 30 \mathrm{ml} / \mathrm{kg}$ compared with the control mice (Figure 1b). We also measured lung EBD and the wet-to-dry weight ratio to determine the effects of mechanical ventilation on changes of microvascular permeability and lung water content in VILI (Figures $1 \mathrm{c}$ and d). Macroscopic lung congestion, lung fibrogenesis, elevated capillary permeability and lung edema induced by high- $\mathrm{V}_{\mathrm{T}}$ mechanical ventilation were substantially suppressed by treatment with PP2 or with Src heterozygous knockout. Moreover, the decreases of the gas exchange $\left(\mathrm{PaO}_{2} / \mathrm{FiO}_{2}\right.$ ratio and alveolar-arterial oxygen gradient (A-aDO2)) in mice receiving $\mathrm{V}_{\mathrm{T}} 30 \mathrm{ml} / \mathrm{kg}$ were substantially improved by PP2 and in Src-deficient mice (Figures 1e and f). PP2 and Src heterozygous knockout also attenuated lung injury in mice subjected to $\mathrm{V}_{\mathrm{T}}$ at $30 \mathrm{ml} / \mathrm{kg}$ without bleomycin administration (the levels of EBD: nonventilated control without bleomycin $=24.1 \pm 1.5 \mathrm{ng} / \mathrm{mg}$ lung weight, $\mathrm{V}_{\mathrm{T}} 30 \mathrm{ml} / \mathrm{kg}=102.3 \pm 4.1 \mathrm{ng} / \mathrm{mg}$ lung weight ${ }^{*}, \mathrm{~V}_{\mathrm{T}} 30 \mathrm{ml} / \mathrm{kg}$, Src-deficient $=53.6 \pm 3.1 \mathrm{ng} / \mathrm{mg}$ lung weight $^{\star}, \mathrm{V}_{\mathrm{T}} 30 \mathrm{ml} / \mathrm{kg}$ pretreated with $\mathrm{PP} 2=68.4 \pm 5.2 \mathrm{ng} / \mathrm{mg}$ lung weight ${ }^{*}$, ${ }^{*} P<0.05$ vs control; wet-to-dry weight ratio: nonventilated control without bleomycin $=3.7 \pm 0.3, \mathrm{~V}_{\mathrm{T}} 30 \mathrm{ml} / \mathrm{kg}=5.7 \pm$ $0.4^{\star}, \mathrm{V}_{\mathrm{T}} 30 \mathrm{ml} / \mathrm{kg}$, Src-deficient $=4.1 \pm 0.3^{\star}, \mathrm{V}_{\mathrm{T}} 30 \mathrm{ml} / \mathrm{kg}$ pretreated with $\mathrm{PP} 2=4.8 \pm 0.4^{\star},{ }^{\star} P<0.05$ vs control; A-aDO2: nonventilated control without bleomycin $=3.3 \pm 0.2, \quad V_{T}$

Table 2 Physiologic conditions at the beginning and end of ventilation

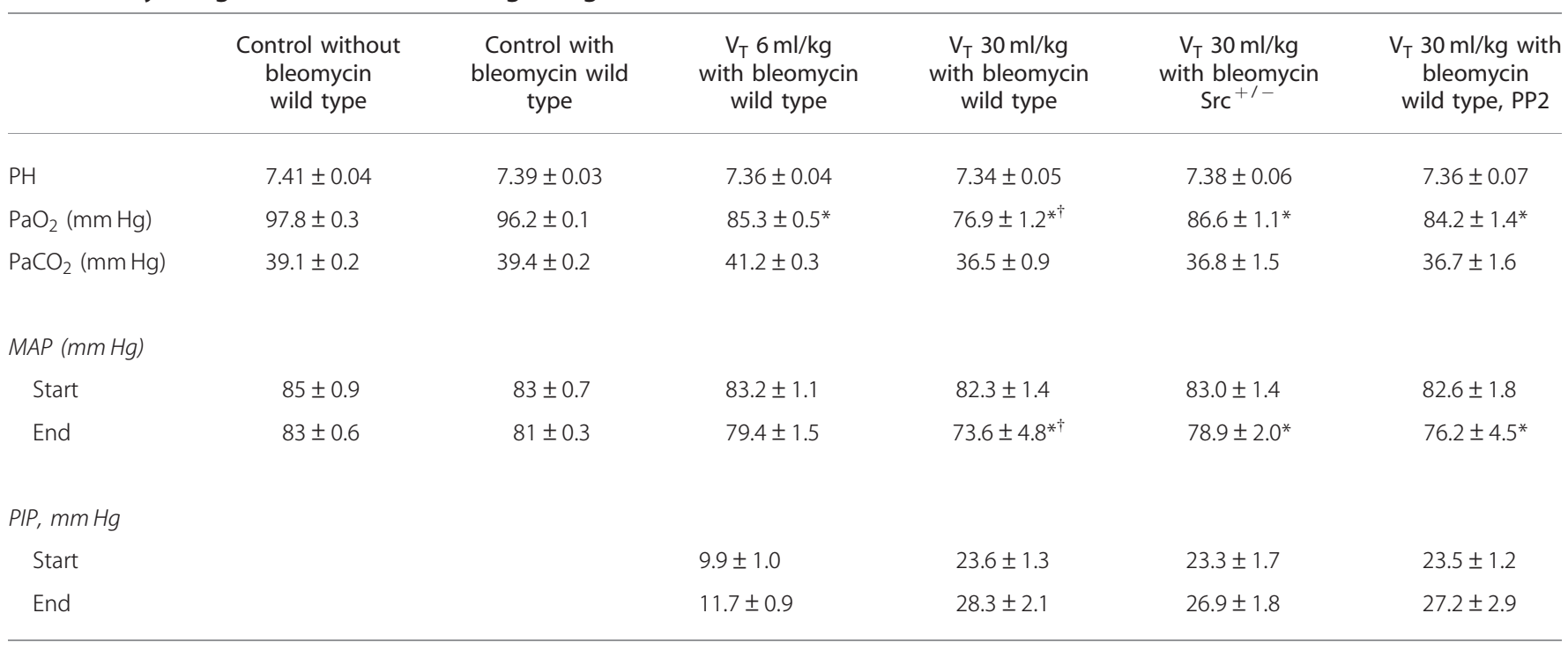

Abbreviations: MAP, mean arterial pressure; PIP, peak inspiratory pressure; $\mathrm{Src}^{+/-}$, Src-deficient mice; $\mathrm{V}_{\mathrm{T}}$, tidal volume.

The physiological data of the control groups were similar during the experiment and were used as the beginning data of ventilation.

At the end of the study period, arterial blood gases and MAP were obtained from the nonventilated control mice and mice subjected to $\mathrm{V}_{\mathrm{T}}$ at $6 \mathrm{ml} / \mathrm{kg}$ or at $30 \mathrm{ml} / \mathrm{kg}$ for $5 \mathrm{~h}$ ( $n=10$ per group). The normovolemic statuses of mice were maintained by monitoring mean artery pressure. Data are presented as mean \pm s.d.

${ }^{*} P<0.05$ vs the nonventilated control mice with bleomycin pretreatment.

${ }^{\dagger} P<0.05$ vs all other groups. 


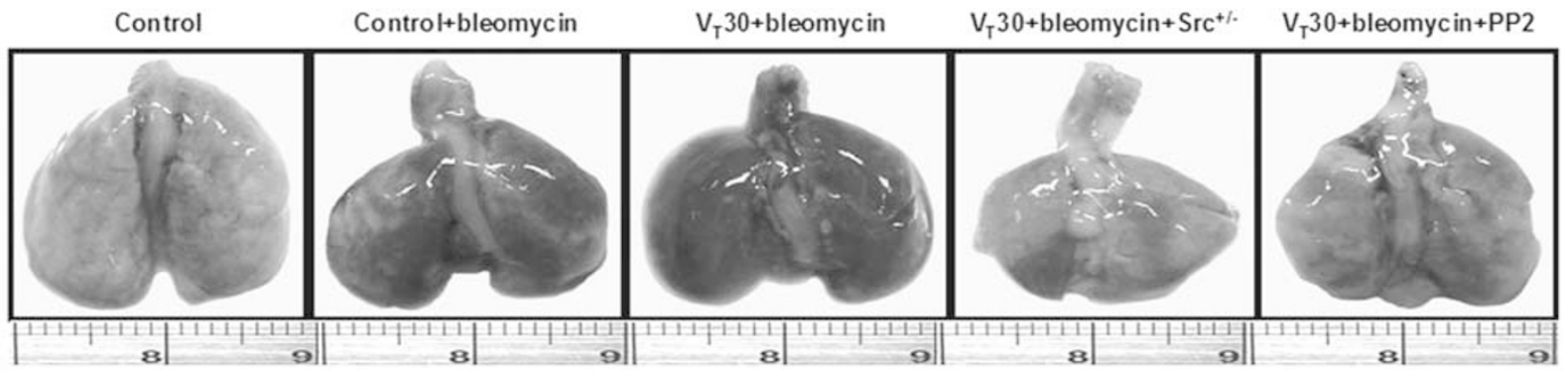

b

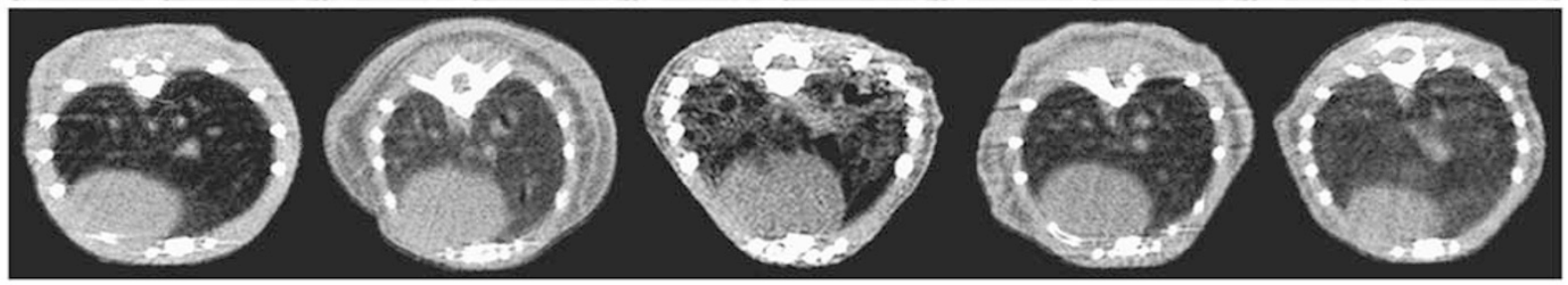

C

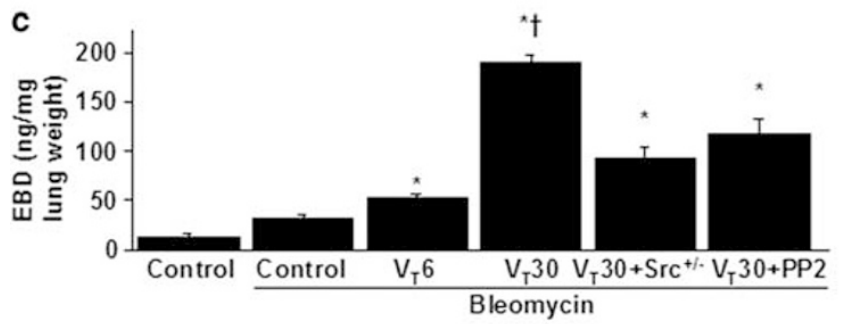

e

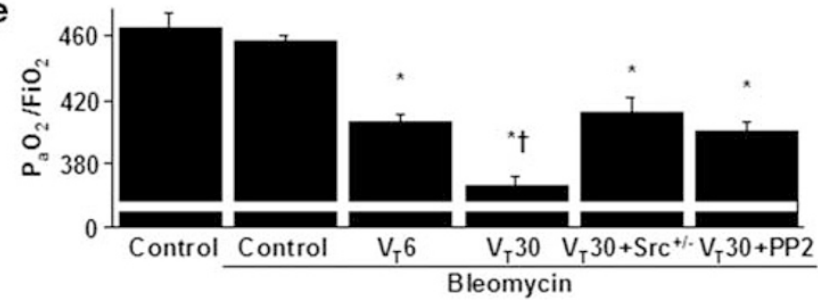

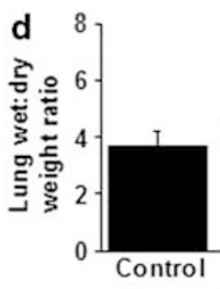
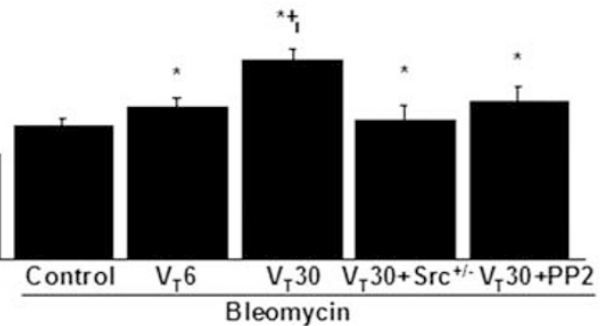

f

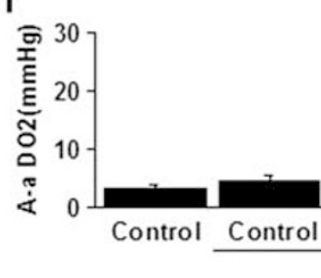

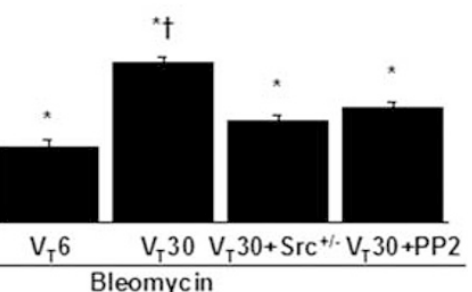

Figure 1 Src-deficient mice and PP2 reduced lung stretch-induced lung damage, microvascular leak, lung edema and hypoxemia. Five days after administering bleomycin, gross pathologic findings (a), micro-computer tomography imaging (b), Evans blue dye (EBD) analysis (c), lung wet-to-dryweight ratio (d), $\mathrm{PaO}_{2} / \mathrm{FiO}_{2}$ (e) and $\mathrm{A}-\mathrm{aDO}_{2}$ (f) were from the nonventilated control mice and those subjected to tidal volume $\left(\mathrm{V}_{\mathrm{T}}\right)$ at $6 \mathrm{ml} / \mathrm{kg}\left(\mathrm{V}_{\mathrm{T}} 6\right)$ or at $30 \mathrm{ml} / \mathrm{kg}\left(\mathrm{V}_{\mathrm{T}} 30\right)$ for $5 \mathrm{~h}$ with room air ( $n=5$ per group). PP2 $2 \mathrm{mg} / \mathrm{kg}$ was given intraperitoneally 30 min before ventilation. ${ }^{*} P<0.05 \mathrm{vs}$ the nonventilated control mice with bleomycin pretreatment; ${ }^{\dagger} P<0.05$ vs all other groups. $\mathrm{A}-\mathrm{aDO}_{2}=$ alveolar-arterial oxygen gradient $=\left(150-1.2 \mathrm{PaCO}{ }_{2}\right)-$ $\mathrm{PaO}_{2} ; \mathrm{FiO}_{2}=$ fraction of inspired oxygen; $\mathrm{Src}^{+/-}=$Src-deficient mice.

$30 \mathrm{ml} / \mathrm{kg}=18.1 \pm 0.4^{*}, \mathrm{~V}_{\mathrm{T}} 30 \mathrm{ml} / \mathrm{kg}, \quad$ Src-deficient $=11.4 \pm$ $0.3^{\star}, \mathrm{V}_{\mathrm{T}} 30 \mathrm{ml} / \mathrm{kg}$ pretreated with $\mathrm{PP} 2=13.5 \pm 0.2^{\star},{ }^{\star} \mathrm{P}<0.05$ $v s$ control). There were no statistically significant differences between EBD and wet-to-dry ratio in wild-type or Src-deficient nonventilated control mice receiving bleomycin treatment (the levels of EBD: wild-type with bleomycin $=38.1 \pm$ $1.8 \mathrm{ng} / \mathrm{mg}$ lung weight $v$ s Src-deficient with bleomycin $=$ $33.6 \pm 1.5 \mathrm{ng} / \mathrm{mg}$ lung weight, $P=0.12$; wet-to-dry weight ratio: wild-type with bleomycin $=4.8 \pm 0.2 \mathrm{vs}$ Src-deficient with bleomycin $=4.6 \pm 0.3, P=0.16)$. These data suggested that inhibiting the Src pathway improves microvascular leakage, lung edema, lung fibrogenesis and helps to recover respiratory functions in a previously bleomycin-injured mouse model of VILI.

\section{Reduction of Inflammatory Cytokine, Collagen Gene Expression and Collagen Fiber Production in the Extracellular Matrix of Src-Deficient Mice and by PP2}

We used Masson's trichrome staining to determine the effects of mechanical ventilation on the accumulated peribronchiolar and parenchymal collagen fibers. We observed increased collagen fibers in the extracellular matrix (ECM) in mice subjected to $\mathrm{V}_{\mathrm{T}}$ at $30 \mathrm{ml} / \mathrm{kg}$ compared with those subjected to $\mathrm{V}_{\mathrm{T}}$ at $6 \mathrm{ml} / \mathrm{kg}$ and nonventilated control mice (Figure 2a). Increased collagen fibers were substantially lower in Srcdeficient mice and pharmacologic inhibition with PP2 measured quantitatively according to total lung collagen content (Figure 2b). We also use real-time PCR to measure the expression of inflammation-associated collagen 1a1, 1a2, 
a
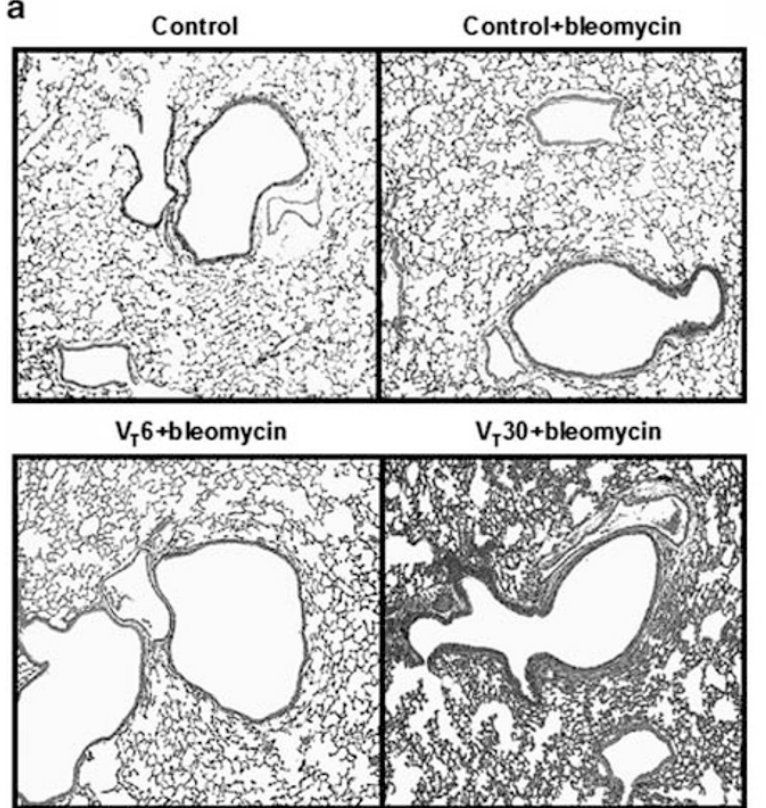

$\mathrm{V}_{\mathrm{T}} 30+$ bleomycin $+\mathrm{Src}^{+-}$

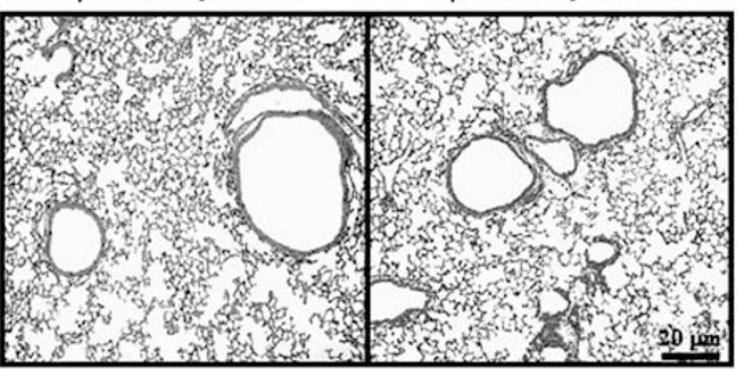

b

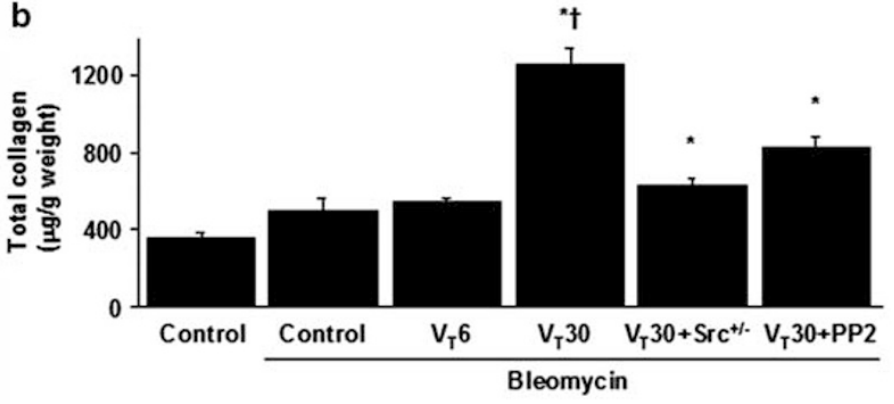

c

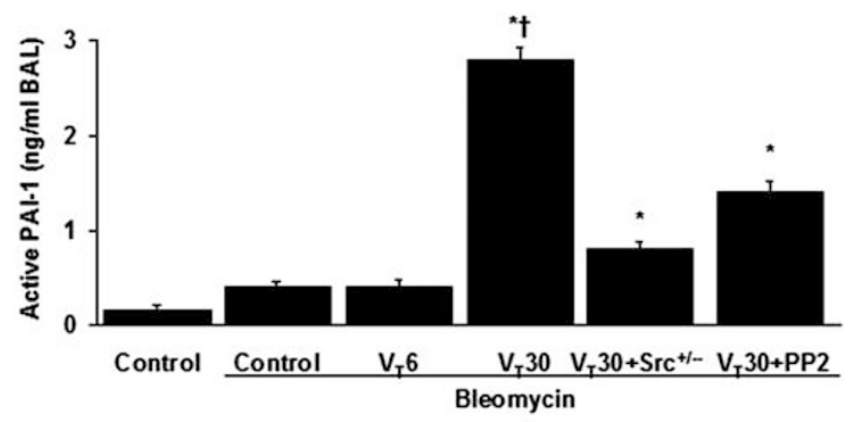

d

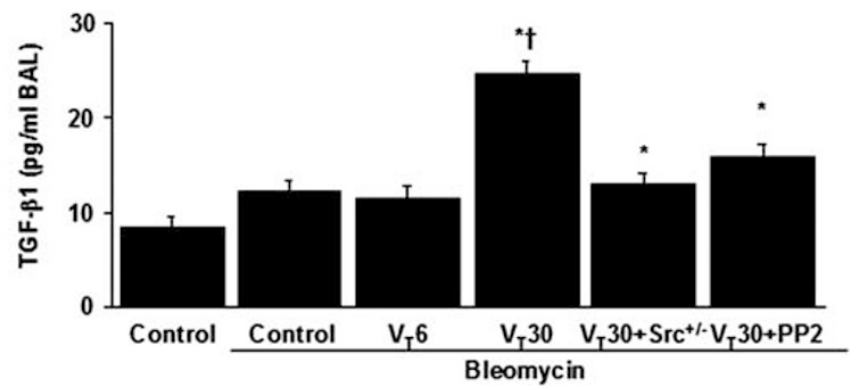

Figure 2 Src-deficient mice and PP2 attenuated lung stretch-induced collagen, PAl- 1 and TGF- $\beta 1$ production. Representative micrographs ( $\times 100$ ) with Masson's trichrome staining of paraffin lung sections (a), total collagen of lung tissue (b), plasminogen activator inhibitor-1 (PAI-1) (c) and transforming growth factor- $\beta 1$ (TGF- $\beta 1$ ) (d) production in bronchoalveolar lavage (BAL) fluid 5 days after bleomycin treatment were from the nonventilated control mice and those subjected to $\mathrm{V}_{\mathrm{T}}$ at $6 \mathrm{ml} / \mathrm{kg}$ or at $30 \mathrm{ml} / \mathrm{kg}$ for $5 \mathrm{~h}$ with room air ( $n=5$ per group). PP2 $2 \mathrm{mg} / \mathrm{kg}$ was given intraperitoneally $30 \mathrm{~min}$ before ventilation. Scale bars represent $20 \mu \mathrm{m}$. ${ }^{*} P<0.05$ vs the nonventilated control mice with bleomycin pretreatment; ${ }^{\dagger} P<0.05$ vs all other groups.

and 3a1. Only collagen 1a1 expression was increased in mice subjected to $V_{\mathrm{T}}$ at $30 \mathrm{ml} / \mathrm{kg}$ compared with those subjected to $\mathrm{V}_{\mathrm{T}}$ at $6 \mathrm{ml} / \mathrm{kg}$ and nonventilated control mice (fold change of collagen 1a1: nonventilated control without bleomycin $=$ $0.5 \pm 0.1$, nonventilated control with bleomycin $=1.0 \pm 0.2$, $\mathrm{V}_{\mathrm{T}} 6 \mathrm{ml} / \mathrm{kg}$ with bleomycin $=1.2 \pm 0.1, \mathrm{~V}_{\mathrm{T}} 30 \mathrm{ml} / \mathrm{kg}$ with bleomycin $=3.4 \pm 0.5^{*}, \quad V_{\mathrm{T}} 30 \mathrm{ml} / \mathrm{kg}, \quad$ Src-deficient $=1.6 \pm$ $0.3^{\star}, \mathrm{V}_{\mathrm{T}} 30 \mathrm{ml} / \mathrm{kg}$ pretreated with $\mathrm{PP} 2=2.4 \pm 0.2^{\star},{ }^{\star} P<0.05$ $v s$ control; fold change of collagen 1a2: nonventilated control with bleomycin $=1.0 \pm 0.2 v s \mathrm{~V}_{\mathrm{T}} 30 \mathrm{ml} / \mathrm{kg}$ with bleomycin $=$ $1.2 \pm 0.1, P=0.21$; fold change of collagen $3 \mathrm{a} 1$ : nonventilated control with bleomycin $=1.0 \pm 0.1$ vs $\mathrm{V}_{\mathrm{T}} 30 \mathrm{ml} / \mathrm{kg}$ with bleomycin $=1.1 \pm 0.2, P=0.23$ ). Furthermore, TGF- $\beta 1$ and PAI-1 production protein levels were elevated in response to $\mathrm{V}_{\mathrm{T}}$ at $30 \mathrm{ml} / \mathrm{kg}$ (Figures $2 \mathrm{c}$ and $\mathrm{d}$ ), indicating an upregulation of proinflammatory and profibrogenic cytokines for fibroblasts in this model. Src heterozygous knockout and pharmacologic inhibition with PP2 substantially reduced collagen 1a1 expression, TGF- $\beta 1$ and PAI-1 elevation associated with VILI.

\section{Inhibition of Mechanical Ventilation-Induced Fibrogenic Markers by Src- Deficient Mice and PP2}

We measured the expression of ZO-1, $\alpha$-SMA and collagen I by using immunofluorescent staining to identify the cells types involved in the lung stretch-induced EMT (Figure 3a). The downregulation of ZO- 1 but the upregulation of $\alpha$-SMA and collagen $I$ in the bronchiolar epithelium and peribronchiolar lung parenchyma were demonstrated in mice subjected to $\mathrm{V}_{\mathrm{T}}$ at $30 \mathrm{ml} / \mathrm{kg}$ compared with the nonventilated control mice, and those subjected to $\mathrm{V}_{\mathrm{T}}$ at $6 \mathrm{ml} / \mathrm{kg}$, indicating a transition from epithelial cells to fibroblasts. Increased expression of ZO-1, but decreased expression of $\alpha$-SMA and collagen I were observed in the Src-deficient mice and pharmacologic inhibition with PP2. To further determine the effects of mechanical ventilation on ECM accumulation, we 
a
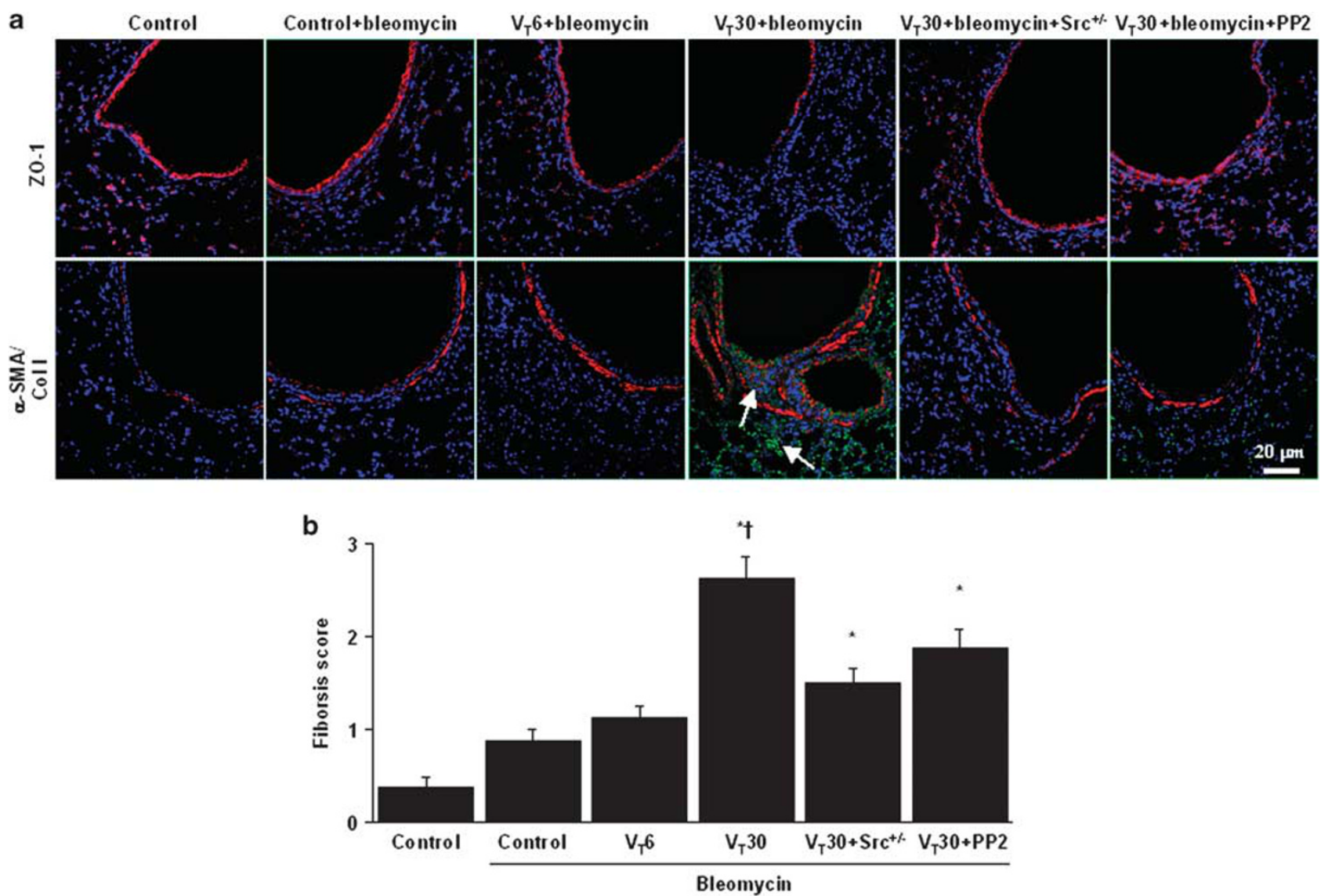

Figure 3 Src-deficient mice and PP2 reduced lung stretch-induced fibrogenic biomarkers. Five days after bleomycin treatment, representative photomicrographs $(\times 400)$ with Zonula occludents-1 (ZO-1, red), $\alpha$-smooth muscle actin $(\alpha$-SMA, red), collagen I (Col I, bright green) and Hoechst (blue) immunofluorescent staining of paraffin lung sections (a) were from the nonventilated control mice and those subjected to $\mathrm{V}_{\mathrm{T}}$ at $6 \mathrm{ml} / \mathrm{kg}$ or at $30 \mathrm{ml} / \mathrm{kg}$ for $5 \mathrm{~h}$ with room air ( $n=5$ per group). PP2 $2 \mathrm{mg} / \mathrm{kg}$ was given intraperitoneally $30 \mathrm{~min}$ before ventilation. Positive red and bright green staining in the lung epithelium and interstitium is identified by arrows ( $n=5$ per group). The fibrotic scoring (b) was quantified as the average number of 10 nonoverlapping fields in Masson's trichrome staining of paraffin lung sections ( $n=5$ per group). Scale bars represent $20 \mu$ m. ${ }^{*} P<0.05$ vs the nonventilated control mice with bleomycin pretreatment; ${ }^{\dagger} P<0.05$ vs all other groups.

conducted fibrosis scoring by using Masson's trichrome staining (Figure 3b). The extent of peribronchiolar ECM deposition increased in mice subjected to $\mathrm{V}_{\mathrm{T}}$ at $30 \mathrm{ml} / \mathrm{kg}$ compared with those subjected to $\mathrm{V}_{\mathrm{T}}$ at $6 \mathrm{ml} / \mathrm{kg}$ and the nonventilated control mice. The fibrosis score of ventilationinduced lung fibrogenesis was significantly lower in the Src-deficient mice and pharmacologic inhibition with PP2.

\section{Suppressing the Mechanical Ventilation-Induced Src Pathway by Src-Deficient Mice and PP2}

Src has been shown to modulate the EMT associated with ALI. ${ }^{19,20}$ Immunohistochemistry indicated that the airway epithelial cells stained positive for phospho-Src after mechanical ventilation at $\mathrm{V}_{\mathrm{T}} 30 \mathrm{ml} / \mathrm{kg}$ (Figures $4 \mathrm{a}$ and $\mathrm{b}$ ). Moreover, we measured Src phosphorylation to further investigate the role of the Src pathway in this VILI model. Consistent with the immunohistochemical results, western blot analyses revealed increased Src phosphorylation in mice subjected to $\mathrm{V}_{\mathrm{T}}$ at $30 \mathrm{ml} / \mathrm{kg}$ and that $\mathrm{Src}$ knockout and inhibition of Src by using PP2 attenuated the high $-\mathrm{V}_{\mathrm{T}^{-}}$ induced phospho-Src activation by $67 \%(P=0.001)$ and $48 \%(P=0.002)$, respectively (Figure $4 \mathrm{c})$. Consistent with previous reports regarding ALI, our data suggested the involvement of the Src pathway in regulating VILI. ${ }^{19,20}$

\section{Inhibition of Src Activation by Src-Deficient Mice and PP2 Reduced Mechanical Ventilation-Induced Lung Inflammation and EMT}

To further determine the roles of fibroblasts involved in the Src activation of lung stretch-induced EMT, we isolated fibroblasts from lung tissue and conducted immunofluorescent staining and western blot analysis to identify their mesenchymal characteristics and Src expression. ${ }^{26}$ Upregulation of $\alpha$-SMA and collagen I, and increased phosphorylation of Src were observed in mice subjected to $V_{T}$ at $30 \mathrm{ml} / \mathrm{kg}$ compared with the nonventilated control mice (Figure 5). The increases of $\alpha$-SMA, collagen I and Src activation were substantially lower in Src-deficient mice and pharmacologic 
a
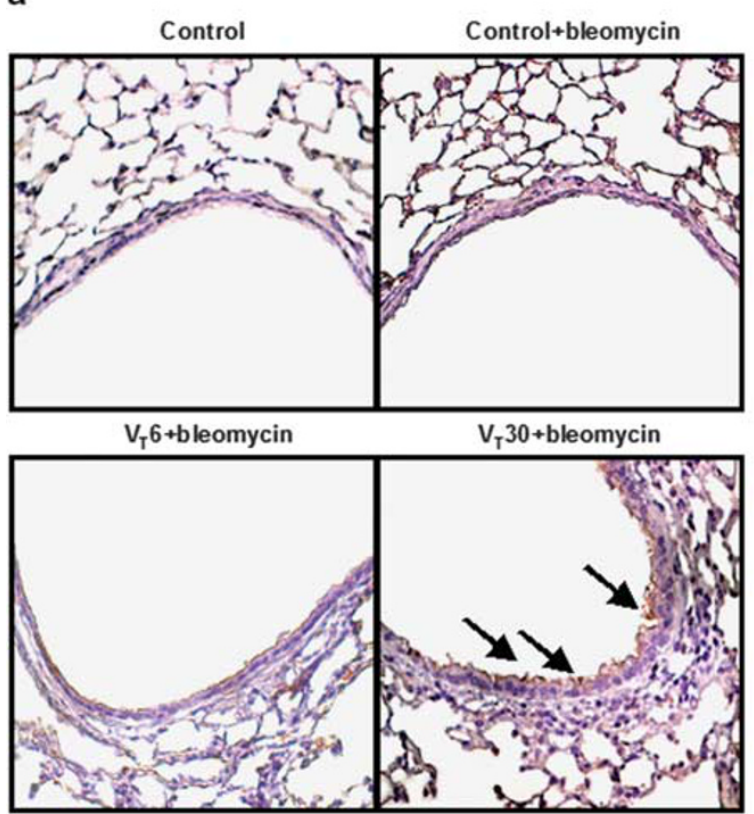

$\mathrm{V}_{\mathrm{T}} 30+$ bleomycin+PP2

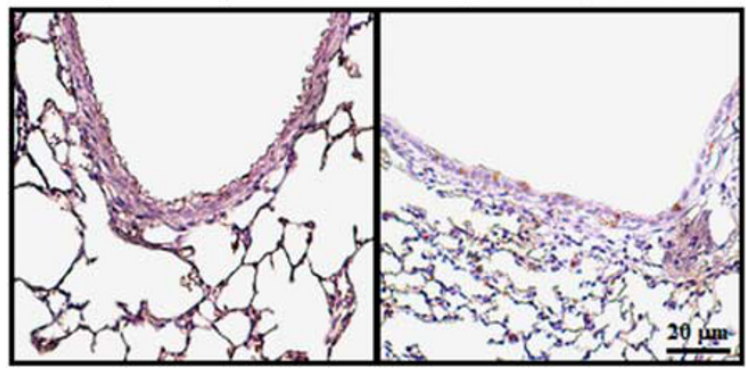

b

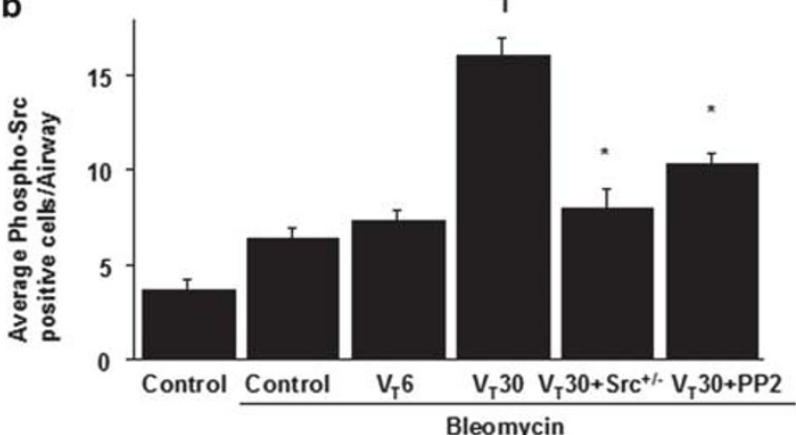

C

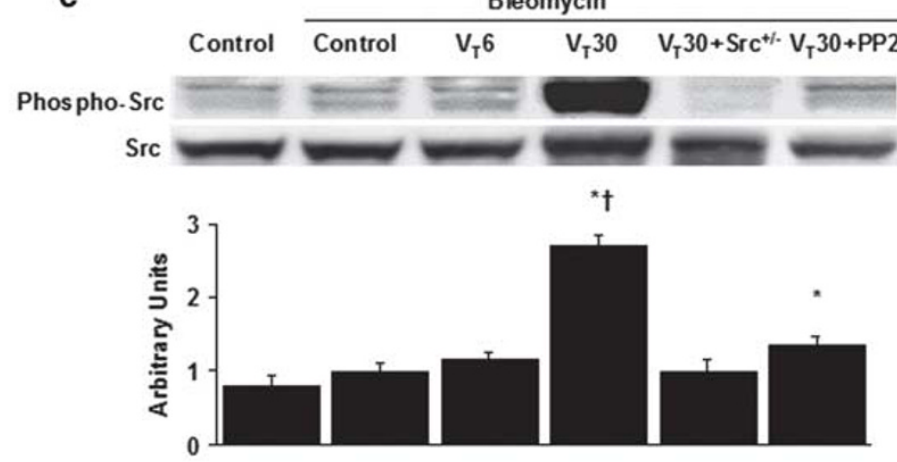

Figure 4 Src-deficient mice and PP2 suppressed lung stretch-induced Src phosphorylation. Representative micrographs $(\times 400)$ with phosphorylated Src staining of paraffin lung sections and quantification $(\mathbf{a}, \mathbf{b}) 5$ days after administering bleomycin were from the nonventilated control mice and those subjected to $V_{T}$ at $6 \mathrm{ml} / \mathrm{kg}$ or at $V_{T} 30 \mathrm{ml} / \mathrm{kg}$ for $5 \mathrm{~h}$ with room air ( $n=5$ per group). Western blot (c) was conducted by using an antibody that recognizes the phosphorylated Src expression and an antibody that recognizes total Src expression in lung tissue from the nonventilated control mice and those subjected to $V_{T}$ at $6 \mathrm{ml} / \mathrm{kg}$ or at $30 \mathrm{ml} / \mathrm{kg}$ for $1 \mathrm{~h}$ with room air $(n=5$ per group). Arbitrary units were expressed as the ratio of phospho-Src to $\operatorname{Src}\left(n=5\right.$ per group). PP2 $2 \mathrm{mg} / \mathrm{kg}$ was given intraperitoneally $30 \mathrm{~min}$ before ventilation. Scale bars represent $20 \mu \mathrm{m}$. ${ }^{*} P<0.05 \mathrm{vs}$ the nonventilated control mice with bleomycin pretreatment; ${ }^{\dagger} P<0.05$ vs all other groups.

inhibition with PP2, indicating that ventilation-induced EMT requires Src signaling. In the course of ARDS, lung inflammation and fibrogenesis to some degree interact. We observed that neutrophil counts and levels of total protein in the BAL fluid increased in mice subjected to $\mathrm{V}_{\mathrm{T}}$ at $30 \mathrm{ml} / \mathrm{kg}$ compared with those subjected to $\mathrm{V}_{\mathrm{T}}$ at $6 \mathrm{ml} / \mathrm{kg}$ and the control mice. Significantly, Src heterozygous knockout and pharmacologic inhibition with PP2 substantially reduced neutrophil infiltration and total protein elevation (neutrophil counts: nonventilated control without bleomycin $=1.2 \pm 0.1$, nonventilated control with bleomycin $=2.3 \pm 0.2, \mathrm{~V}_{\mathrm{T}} 6 \mathrm{ml} / \mathrm{kg}$ with bleomycin $=5.9 \pm 0.4^{*}, \mathrm{~V}_{\mathrm{T}} 30 \mathrm{ml} / \mathrm{kg}$ with bleomycin $=$ $42.1 \pm 2.5^{\star}, \quad V_{\mathrm{T}} \quad 30 \mathrm{ml} / \mathrm{kg}, \quad$ Src-deficient $=21.9 \pm 1.3^{\star}, \quad \mathrm{V}_{\mathrm{T}}$ $30 \mathrm{ml} / \mathrm{kg}$ pretreated with $\mathrm{PP} 2=27.6 \pm 3.4^{*} \times 10^{4} / \mathrm{ml} \mathrm{BAL}$, ${ }^{\star} P<0.05$ vs control; total protein: nonventilated control without bleomycin $=0.22 \pm 0.1$, nonventilated control with bleomycin $=0.38 \pm 0.1, \mathrm{~V}_{\mathrm{T}} 6 \mathrm{ml} / \mathrm{kg}$ with bleomycin $=0.41 \pm$ $0.2, \mathrm{~V}_{\mathrm{T}} 30 \mathrm{ml} / \mathrm{kg}$ with bleomycin $=0.98 \pm 0.3^{*}, \mathrm{~V}_{\mathrm{T}} 30 \mathrm{ml} / \mathrm{kg}$, Src-deficient $=0.47 \pm 0.2^{\star}, \quad \mathrm{V}_{\mathrm{T}} 30 \mathrm{ml} / \mathrm{kg}$ pretreated with $\mathrm{PP} 2=0.62 \pm 0.1^{\star} \mathrm{mg} / \mathrm{ml} \mathrm{BAL},{ }^{\star} P<0.05 v s$ control) .

\section{Reduced Mechanical Ventilation-Induced Epithelial Apoptosis by Src-Deficient Mice and PP2}

As upregulating Src has been associated with stretch-induced pathway-driven lung inflammation, we performed transmission electron microscopy and TUNEL staining to determine the effects of Src deficiency in mice and PP2 on ventilationinduced apoptosis of airway epithelial cells (Figure 6). The epithelial apoptosis was confirmed by the characteristic nuclear condensation of bronchial epithelium in mice 

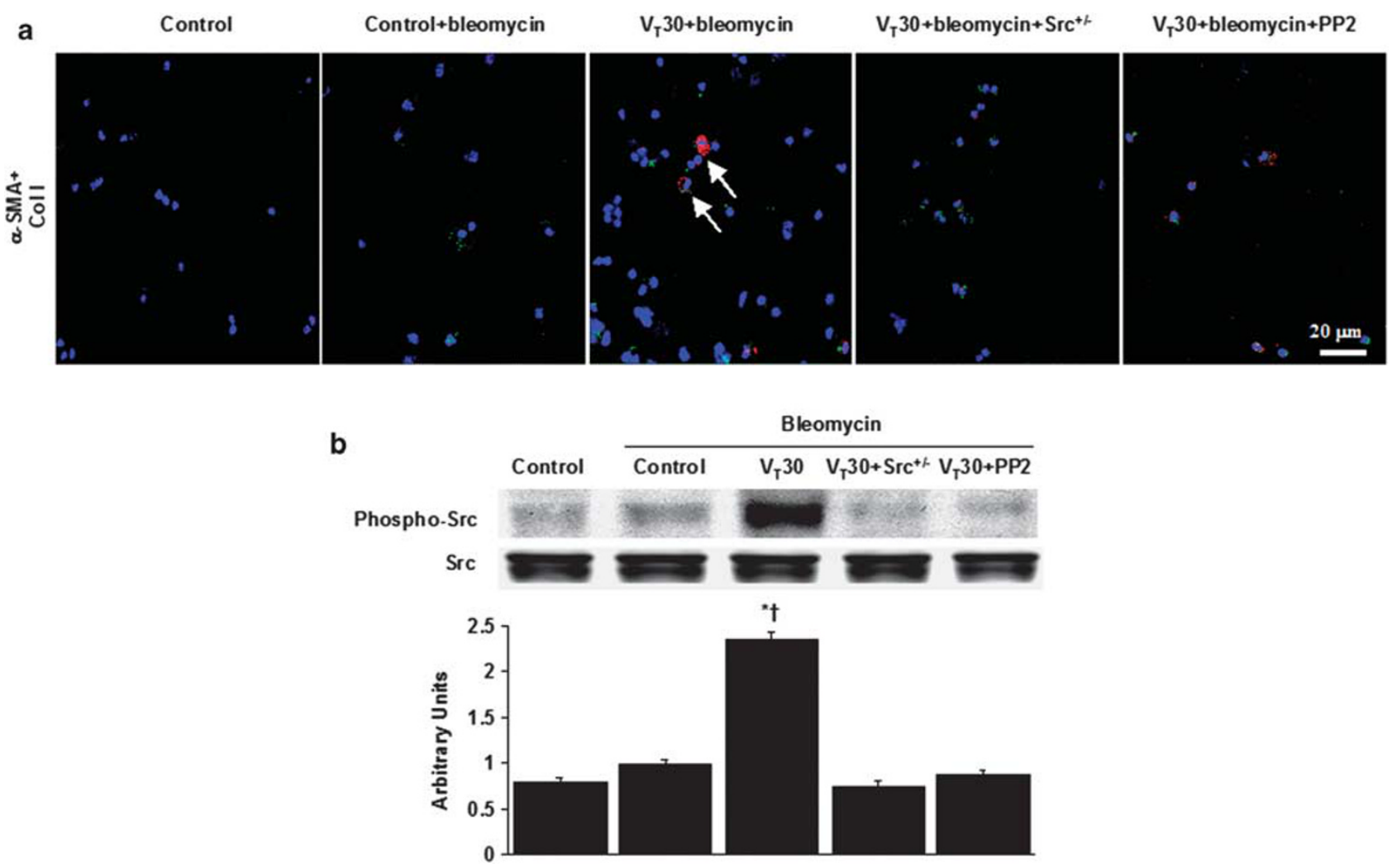

Figure 5 Src-deficient mice and PP2 abrogated lung stretch-induced epithelial-mesenchymal transition and Src phosphorylation in fibroblasts. Five days after administering bleomycin, representative micrographs $(\times 400)$ with $\alpha$-smooth muscle actin $(\alpha$-SMA, red), collagen I (Col I, bright green) and Hoechst (blue) immunofluorescent staining of fibroblasts (a) were from the nonventilated control mice and those subjected to $V_{T}$ at $30 \mathrm{ml} / \mathrm{kg}$ for $5 \mathrm{~h}$ with room air ( $n=5$ per group). Positive red and bright green staining in the fibroblasts is identified by arrows ( $n=5$ per group). Western blot (b) was performed using an antibody that recognizes the phosphorylated Src expression and an antibody that recognizes total Src expression in isolated fibroblasts from the nonventilated control mice and those subjected to $\mathrm{V}_{\mathrm{T}}$ at $30 \mathrm{ml} / \mathrm{kg}$ for $1 \mathrm{~h}$ with room air ( $n=5$ per group). Arbitrary units were expressed as the ratio of phospho-Src to Src ( $n=5$ per group). PP2 $2 \mathrm{mg} / \mathrm{kg}$ was given intraperitoneally $30 \mathrm{~min}$ before ventilation. Scale bars represent $20 \mu \mathrm{m}$. ${ }^{*} P<0.05$ vs the nonventilated control mice with bleomycin pretreatment; ${ }^{\dagger} P<0.05$ vs all other groups.

receiving high- $V_{\mathrm{T}}$ mechanical ventilation. The increases of $\mathrm{V}_{\mathrm{T}} 30$-induced epithelial apoptosis lowered after Src heterozygous knockout and pharmacologic inhibition with PP2.

\section{DISCUSSION}

Although previous studies have demonstrated the role of Src in developing EMT associated with tumorigenesis, the relationship between mechanical ventilation-induced EMT and the Src signaling pathway is unclear. ${ }^{14}$ VILI is characterized by enhanced alveolar-capillary membrane permeability and pulmonary edema, increased inflammatory cytokines, and inflammatory-associated collagen formation, ultimately leading to severe hypoxemia and reduced pulmonary compliance. ${ }^{15}$ The impaired gas exchange and lung fibrogenesis can occur in the first week of the fibroproliferative phase of ARDS, which is similar to that observed in the fibrogenesis model following bleomycin exposure. ${ }^{5,29}$ A previous study of an acid-induced lung injury model in mice also showed the crucial role of mechanical ventilation in initiating lung fibrogenesis, which was associated with TGF- $\beta$ 1-induced EMT and lung fibroblast proliferation. ${ }^{3}$ Recent studies using alveolar type II epithelial cells and rats have demonstrated that cyclic mechanical stretch can lead to disorganization and ECM remodeling of the lung by activating the $\mathrm{Wnt} / \beta$-catenin pathway and inducing EMT. ${ }^{6,7}$ In the current mouse model of VILI, we demonstrated that mechanical ventilation of bleomycintreated lungs of mice increased lung fibrogenesis, lung edema, microvascular permeability, fibroblast accumulation, epithelial apoptosis, hypoxemia, and PAI-1 and TGF- $\beta 1$ production. Upregulation of Src is associated with increased lung injury. We further explored the roles of alveolar epithelia, fibroblasts and Src activation in the fibrogenesis of VILI.

Fibroblasts and myofibroblasts are the predominant cell types involved in pulmonary fibrogenesis and can originate from local precursors such as interstitial fibroblasts, from EMT of abnormally activated alveolar epithelium, or from circulating fibrocytes derived from bone marrow recruited to the lung..$^{18,30}$ Three primary factors driving the differentiation of fibroblasts to myofibroblasts are high mechanical 

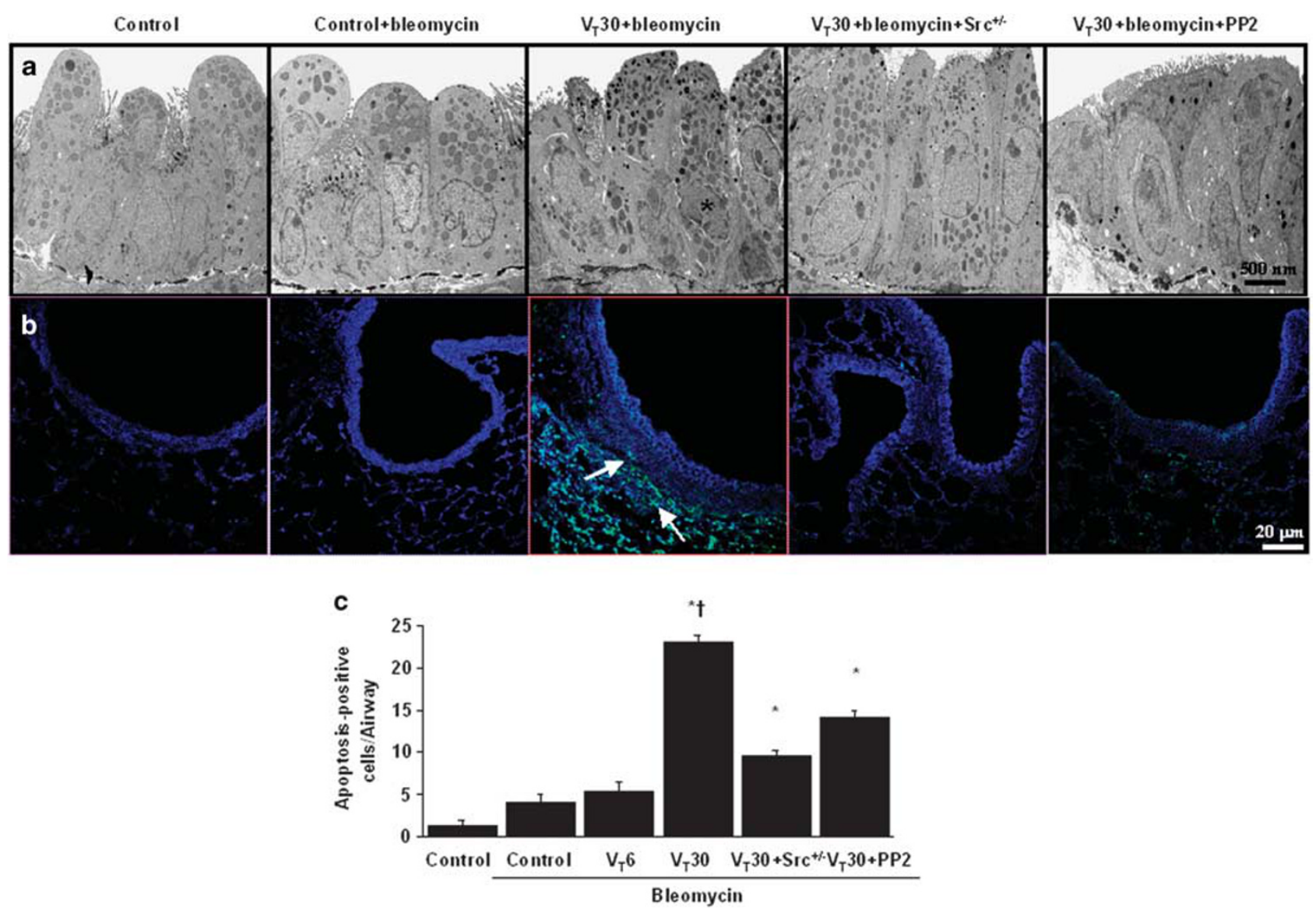

Figure 6 Src-deficient mice and PP2 attenuated lung stretch-induced bronchial epithelial apoptosis. Representative micrographs with transmission electron microscopic image $(\mathbf{a}, \times 6000)(n=3$ per group) and TUNEL staining $(\mathbf{b}, \mathbf{c}, \times 400)(n=5$ per group) of the paraffin lung sections 5 days after bleomycin treatment were from the nonventilated control mice and those subjected to $V_{T}$ at $6 \mathrm{ml} / \mathrm{kg}$ or at $30 \mathrm{ml} / \mathrm{kg}$ for $5 \mathrm{~h}$ with room air. Apoptosispositive cells were quantified as the average number of epithelial cells with bright green signals per bronchiole, which were counted from 10 nonoverlapping fields of each section ( $n=5$ per group). PP2 $2 \mathrm{mg} / \mathrm{kg}$ was given intraperitoneally $30 \mathrm{~min}$ before ventilation. Apoptotic cells are identified by asterisks or arrows. A bright green signal indicates positive staining of apoptotic cells, and shades of dull green signify non-reactive cells. Scale bars represent $500 \mathrm{~nm}$ or $20 \mu \mathrm{m}$. ${ }^{*} P<0.05$ vs the nonventilated control mice with bleomycin pretreatment; ${ }^{\dagger} P<0.05$ vs all other groups. TUNEL $=$ terminal deoxynucleotidyl transferase-mediated dUTP-biotin nick end-labeling.

stresses, local increase of TGF- $\beta 1$ and the presence of the extra domain A splice variant of fibronectin. ${ }^{12}$ TGF- $\beta 1$ is a multifunctional cytokine that has a vital role in modifying lung permeability, epithelial ion transport, fibrinolysis, ECM deposition and surfactant homeostasis and can induce the cytoskeletal reorganization observed in EMT. ${ }^{11}$ A previous study of patients with lung fibrogenesis revealed that engaging the $\alpha \mathrm{v} \beta 6$ integrin of epithelial cells to fibronectin may trigger the activation and production of TGF- $\beta 1 .^{10}$ Moreover, epithelial cells can promote lung fibrogenesis by acquiring a mesenchymal phenotype through the mediation of TGF- $\beta 1 .{ }^{10}$ Previous studies of ARDS patients have also demonstrated that alveolar fibroblasts can be cultured in the organic phase of ARDS patients, and blocking the TGF- $\beta 1$ receptor can attenuate lung fibrogenesis. ${ }^{30,31}$ Increased production of TGF- $\beta 1$ can bind to ECM, which is responsible for transmitting mechanical stretch between cells. ${ }^{32}$ Disturbances in coagulation and fibrinolysis, related to elevated pulmonary concentrations of PAI-1, have been demonstrated in patients with ARDS. ${ }^{33}$ A previous murine model of lung fibrogenesis caused by injurious mechanical ventilation showed that TGF- $\beta 1$ induced the production of PAI-1 and administering PAI-1 RNA interference inhibited EMT and the progression of pulmonary fibrogenesis. ${ }^{8,9,15}$ TGF- $\beta 1$ can inhibit collagen degradation by inducing PAI-1 expression and thus inhibiting the activities of plasmin and tPA. $^{15}$ We demonstrated that high- $\mathrm{V}_{\mathrm{T}}$ mechanical ventilation increased lung injury, collagen deposition, fibroblast accumulation, increased expression of mesenchymal markers $\alpha$-SMA and type I collagen, but decreased epithelial marker ZO- 1 , and PAI- 1 and TGF- $\beta 1$ production.

The Src protein tyrosine kinase is expressed by macrophages, monocytes, neutrophils, alveolar epithelial cells, endothelial cells and fibroblasts in the lung. ${ }^{14} \mathrm{~A}$ previous study of injurious mechanical ventilation in an isolated perfused murine lung demonstrated that mechanical 
ventilation increased vascular permeability and edema formation by activating phosphoinositide $3-\mathrm{OH}$ kinase $(\mathrm{PI} 3 \mathrm{~K})$ and $\mathrm{Src}$ protein tyrosine kinases. ${ }^{13}$ Mechanical ventilation can increase Src phosphorylation by activating adherens junctions, $\mathrm{Ca}^{2+}$ entry through stretch-activated cation channels, deformation of cytoskeleton and integrins, focal adhesion kinases, G protein-coupled receptors, and growth factor receptors. ${ }^{13}$ In the presence of active TGF- $\beta 1$ and disrupted cell contacts of the bleomycin mouse model, integrin mediated Src activation after TGF- $\beta 1$ signaling and Src inhibition blocked EMT and fibrogenesis. ${ }^{34}$ Our results revealed that mechanical ventilation induced the phosphorylation of Src both in lung tissue and isolated myofibroblasts, which can be suppressed by Src knockout or pharmacologic inhibition with PP2, a selective Src kinase inhibitor remaining effective up to $6 \mathrm{~h}$ after ALI. ${ }^{14,20,22}$ However, PP2 is a hydrophobic chemical and can only be dissolved in the toxic organic solvent dimethyl sulfoxide. The recent development of nanoscale combinations of self-assembling peptides (EAK16-II) and amino acids can improve the biocompatibility of previous PP2 formulation and advance its potential clinical use. ${ }^{35}$

Severe lung injury has been known to cause apoptotic cell death. ${ }^{19,20,34}$ The effects of apoptosis vary with cell types and TGF- $\beta 1$ has been shown to enhance the apoptotic response of epithelial cells by activating the Fas/Fas ligand pathway. ${ }^{36}$ Recent studies of endoplasmic reticulum stress-induced EMT in alveolar epithelial cells and ischemia-reperfusion-induced ALI of rat have shown that apoptotic cell death, in a Src kinase-dependent manner, may represent an escape mechanism for the stressed cells to reduce production of inflammatory proteins and rely on the duration and extent of epithelial cell injury. ${ }^{19-21}$ We demonstrated that high- $\mathrm{V}_{\mathrm{T}}$ mechanical ventilation-induced apoptosis of murine airway epithelial cells with characteristic findings of highly condensed and fragmented heterochromatin. Apoptotic cell death, lung injury, severe hypoxemia and computer tomographic findings of fibrogenesis, such as reticular abnormality and honeycombing were attenuated in Src-deficient mice and pharmacologic inhibition with PP2, suggesting the involvement of the Src pathway in regulating EMT and epithelial apoptosis.

This study had some limitations. Partial inhibition of lung injury through Src knockout or pharmacologic inhibition with PP2, compared with the control mice, suggested that Src signaling was only one of the many pathways contributing to ventilation-induced EMT. Despite its extensive use as a Srcselective inhibitor, recent studies have demonstrated that PP2 also reduced the activation of serine/threonine kinase/protein kinase $\mathrm{B}$, beta-catenin, Jak kinase and phosphoinositide 3-OH kinase. ${ }^{13,22}$ Further experiments are necessary to explore potential regulators of VILI.

By using an in vivo mouse model of bleomycin-induced ALI, we demonstrated that high- $V_{\mathrm{T}}$ mechanical ventilationinduced lung inflammation-associated EMT and epithelial apoptosis are modulated by Src kinase and the production of PAI- 1 and TGF- $\beta 1$. Knowledge of the effect of mechanical forces on Src signaling allowed clarification of the pathophysiologic mechanisms regulating the reparative phase of ARDS, which can progress to irreversible pulmonary fibrogenesis and require long-term dependence of a ventilator. Therefore, inhibiting Src, an inflammation modulator, may serve as a novel therapeutic target for preventing and treating patients with ARDS. Further identifying the mechanisms regulating the organic phase of ARDS is necessary for developing enhanced management of various types of ALI.

\section{ACKNOWLEDGMENTS}

This research was supported by a grant from the National Science Council (no. 101-2314-B-182A-088-MY3). We thank Wei-Han Lin, Molecular Imaging Center, and Microscope Core Laboratory, Chang Gung Memorial Hospital, Linkou for their help with the experiment.

\section{DISCLOSURE/CONFLICT OF INTEREST}

The authors declare no conflict of interest.

1. Reiss LK, Uhlig U, Uhlig S. Models and mechanisms of acute lung injury caused by direct insults. Eur J Cell Biol 2012;91:590-601.

2. Held HD, Boettcher $S$, Hamann $L$, et al. Ventilation-induced chemokine and cytokine release is associated with activation of nuclear factor- $\kappa \mathrm{B}$ and is blocked by steroids. Am J Respir Crit Care Med 2001;163: 711-716.

3. Cabrera-Benítez NE, Parotto M, Post M, et al. Mechanical stress induces lung fibrosis by epithelial-mesenchymal transition. Crit Care Med 2012;40:1-8.

4. Martin C, Papazian L, Payan MJ, et al. Pulmonary fibrosis correlates with outcome in adult respiratory distress syndrome. A study in mechanically ventilated patients. Chest 1995;107:196-200.

5. Li LF, Liao SK, Huang CC, et al. Serine/threonine kinase-protein kinase $B$ and extracellular signal-regulated kinase regulate ventilator-induced pulmonary fibrosis after bleomycin-induced acute lung injury: a prospective, controlled animal experiment. Crit Care 2008;12:R103.

6. Heise RL, Stober V, Cheluvaraju C, et al. Mechanical stretch induced epithelial-mesenchymal transition in alveolar epithelia via hyaluronan activation of innate immunity. J Biol Chem 2011;286:17435-17444.

7. Villar J, Cabrera NE, Valladares F, et al. Activation of the Wnt/ $\beta$-catenin signaling pathway by mechanical ventilation is associated with ventilator-induced pulmonary fibrosis in healthy lungs. PLoS One 2011;6:e23914.

8. Dahlem P, Bos AP, Haitsma JJ, et al. Alveolar fibrinolytic capacity suppressed by injurious mechanical ventilation. Intensive Care Med 2005;31:724-732.

9. Senoo T, Hattori N, Tanimoto $T$, et al. Suppression of plasminogen activator inhibitor-1 by RNA interference attenuates pulmonary fibrosis. Thorax 2010;65:334-340.

10. Marmai C, Sutherland RE, Kim KK, et al. Alveolar epithelial cells express mesenchymal proteins in patients with idiopathic pulmonary fibrosis. Am J Physiol Lung Cell Mol Physiol 2011;301:L71-L78.

11. Wesselkamper SC, Case LM, Henning LN, et al. Gene expression changes during the development of acute lung injury-role of transforming growth factor $\beta$. Am J Respir Crit Care Med 2005;172: 1399-13411.

12. King Jr TE, Pardo A, Selman M. Idiopathic pulmonary fibrosis. Lancet 2011;378:1949-1961.

13. Miyahara T, Hamanaka K, Weber DS, et al. Phosphoinositide 3-kinase, Src, and Akt modulate acute ventilation-induced vascular permeability increases in mouse lungs. Am J Physiol Lung Cell Mol Physiol 2007;293:L11-L21.

14. Okutani D, Lodyga $M$, Han $B$, et al. Src protein tyrosine kinase family and acute inflammatory responses. Am J Physiol Lung Cell Mol Physiol 2006;290:L622-L645. 
15. Liu RM. Oxidative stress, plasminogen activator inhibitor 1, and lung fibrosis. Antioxid Redox Signal 2008;10:303-319.

16. Fahy RJ, Lichtenberger $F$, McKeegan $C B$, et al. The acute respiratory distress syndrome- a role for transforming growth factor- $\beta 1$. Am J Respir Cell Mol Biol 2003;28:499-503.

17. Araya J, Nishimura SL. Fibrogenic reactions in lung disease. Annu Rev Pathol Mech Dis 2010;5:77-98.

18. Strieter RM, Mehrad B. New mechanisms of pulmonary fibrosis. Chest 2009;136:1364-1370.

19. Oyauzu T, Fung SY, Shiozaki A, et al. Src tyrosine kinase inhibition prevents pulmonary ischemia-reperfusion-induced acute lung injury. Intensive Care Med 2012;38:894-905.

20. Zhong $Q$, Zhou B, Ann DK, et al. Role of endoplasmic reticulum stress in epithelial-mesenchymal transition of alveolar epithelial cells. Am J Respir Cell Mol Biol 2011;45:498-509.

21. Tanjore H, Cheng DS, Degryse AL, et al. Alveolar epithelial cells undergo epithelial to mesenchymal transition in response to endoplasmic reticulum stress. J Biol Chem 2011;286:30972-30980.

22. Severgnini $M$, Takahashi $S$, Tu $P$, et al. Inhibition of the Src and Jak kinases protects against lipopolysaccharide-induced acute lung injury. Am J Respi Crit Care Med 2005;171:858-867.

23. Pechkovsky DV, Scaffidi AK, Hackett TL, et al. Transforming growth factor $\beta 1$ induces $\alpha v \beta 3$ integrin expression in human lung fibroblasts via a $\beta 3$ integrin-, c-Src-, and p38 MAPK-dependent pathway. J Bio Chem 2008:283:12898-12908.

24. Soriano P, Montgomery C, Geske R, et al. Targeted disruption of the c-src proto-oncogene leads to osteopetrosis in mice. Cell 1991;64: 693-702.

25. Maniatis NA, Kardara M, Hecimovich $D$, et al. Role of caveolin-1 expression in the pathogenesis of pulmonary edema in ventilatorinduced lung injury. Pulm Circ 2012;2:452-460.
26. Kass D, Bridges RS, Borczuk A, et al. Methionine aminopeptidase-2 as a selective target of myofibroblasts in pulmonary fibrosis. Am J Respir Cell Mol Biol 2007;37:193-201.

27. Jin GY, Bok SM, Han YM, et al. Effectiveness of rosiglitazone on bleomycin-induced lung fibrosis: assessed by micro-computed tomography and pathologic scores. Eur J Radiol 2012;81:1901-1906.

28. Zhang $\mathrm{W}$, Chancey $\mathrm{AL}$, Tzeng HP, et al. The development of myocardial fibrosis in transgenic mice with targeted overexpression of tumor necrosis factor requires mast cell-fibroblast interactions. Circulation 2011;124:2106-2116.

29. Tanjore $\mathrm{H}, \mathrm{Xu} X \mathrm{X}$, Polosukhin VV, et al. Contribution of epithelialderived fibroblasts to bleomycin-induced lung fibrosis. Am J Respir Crit Care Med 2009;180:657-665

30. Quesnel C, Nardelli L, Piednoir P, et al. Alveolar fibroblasts in acute lung injury: biological behaviour and clinical relevance. Eur Respir J 2010;35:1312-1321.

31. Weiss $\mathrm{CH}$, Budinger GRS, Mutiu GM, et al. Proteasomal regulation of pulmonary fibrosis. Proc Am Thorac Soc 2010;7:77-83.

32. Ludwig MS. Proteoglycans and pathophysiology. J Appl Physiol 2007;103:735-736.

33. El Solh AA, Bhora M, Pineda $L$, et al. Alveolar plasminogen activator inhibitor-1 predicts ARDS in aspiration pneumonitis. Intensive Care Med 2006:32:110-115.

34. Ulsamer A, Wei Y, Kim KK, et al. Axin pathway activity regulates in vivo pY654- $\beta$-catenin accumulation and pulmonary fibrosis. J Biol Chem 2012;287:5164-5172.

35. Fung SY, Oyaizu $\mathrm{T}$, Yang $\mathrm{H}$, et al. The potential of nanoscale combinations of self-assembling peptides and amino acids of the Src tyrosine kinase inhibitor in acute lung injury. Biomaterials 2011;32:4000-4008.

36. Matute-Bello G, Martin TR. Science review: apoptosis in acute lung injury. Crit Care 2003;7:355-358. 